an elderly relation of one of her house-boys, who had told his family that they must bring any lost or injured bird they found to her. Perhaps a practical demonstration such as hers of the value placed on these small lives may do more to convince simple people of the merits of conservation than a mountain of propaganda.

DIANA SPEARMAN

\title{
Whaler's Eye, by Christopher Ash. Allen and Unwin, 32 s.
}

As chief chemist on board the factory ship Balaena, the author has travelled south nearly every year since 1944, so he writes with authority about the whaling industry, which seems to be intent on destroying itself. In this glimpse into the fascinating world of the whaler, his deep concern with the fortunes of the industry, and knowledge of its operations, enable him to bring every aspect vividly to the reader, guiding him through the maze of pipes below decks on the factory, or across the slippery decks to show the processes which start with the magnificent whale and end in the clear oil, so valuable that millions are spent harvesting it. His understanding of both sides of the controversy over the morals of whaling is revealed in his imaginary dialogues. This is the most readable book on whaling for many years, and all who love the sea, whether whale men or not, will enjoy it.

ARTHUR BOURNE

\section{DEATHS AMONG CAPTURED ANIMALS}

A MEMBER of the FPS in Malaya, Mr. W. P. Macveigh, has sent us his $\mathrm{A}_{\text {comments on the mortality figures among wild animals and birds after }}$ capture in Kenya quoted by Major Ian Grimwood at the Symposium on "Zoos and Conservation" reported in the August issue of ORYX, page 215 :

I have a small collection of mammals and birds in my grounds heresome of the latter have been bred in the aviaries and I have from time to time exported abroad. In my view high mortality, particularly in birds, is due to the following basic causes:-

(a) Zoos and private collectors are in many cases too intent on competitive prices.

(b) As a result dealers in the U.S. and Europe (especially the Continent) buy from "cheap" suppliers accepting a high mortality rate in view of the low cost.

(c) In Malaysia those exporters quoting " cheap" prices are for that very reason persons with little knowledge or interest in their stock-their export packing is low grade to maintain low freight (air) for the benefit of their consignees.

However, if one supplies only healthy specimens in correct packing, such as I have devised myself (not as recommended by the Airways) and in addition sees that all specimens are maintained in aviaries and conditioned to captivity before despatch by air, then mortality can be reduced to nil and I have never lost a bird in transit; I only supply selected pairs to private aviculturists or zoos, not in quantity to overseas dealers.

I would guess that the lovebirds referred to by Major Grimwood had been caged together and mortality was due to fighting and trampling. In Malaya we have a small psittacine Loriculus galgalus with characteristics similar to lovebirds. If kept in roomy cages or aviaries (clean), deaths from fighting are not to be feared-however, when shipping by air I provide each specimen with a separate compartment as otherwise high mortality may be expected. 